\title{
Analisis UU No. 34 Tahun 2004 Tentang Kedudukan dan Peran TNI dalam Lembaga Pemerintahan Negara
}

\author{
Muhammad Hendrik Novavah ${ }^{1}$ \\ ${ }^{1}$ Fakultas Syariah, IAIN Jember. E-mail: hendrikhijauhitam090@gmail.com
}

\begin{tabular}{|c|c|}
\hline Article & bstract \\
\hline $\begin{array}{l}\text { How to cite: } \\
\text { Muhammad Hendrik } \\
\text { Novavah, 'Analisis UU } \\
\text { No. } 34 \text { Tahun } 2004 \\
\text { Tentang Kedudukan dan } \\
\text { Peran TNI dalam } \\
\text { Lembaga Pemerintahan } \\
\text { Negara' (2020) Vol. } 1 \text { No. } \\
1 \text { Rechtenstudent Journal } \\
\text { Fakultas Syariah IAIN } \\
\text { Jember. } \\
\text { Histori artikel: } \\
\text { Submit } 4 \text { Februari 2020; } \\
\text { Diterima } 2 \text { Maret 2020; } \\
\text { Diterbitkan } 3 \text { April 2020. } \\
\text { ISSN: } \\
\text { 2723-0406 (media cetak) }\end{array}$ & $\begin{array}{l}\text { The military in Indonesia has been heavily involved in socio-political life in } \\
\text { determining state policy. This involvement in the socio-political realm that began in } \\
\text { 1945-1998 was known as the dual function of ABRI. However, the concept of ABRI's } \\
\text { dual function is seen as the cause of the failure of the existing government system in } \\
\text { Indonesia. With the many demands for reform and the fall of the New Order regime, } \\
\text { in } 2000 \text { to be precise in May the concept of Dwifungsi was officially removed from } \\
\text { the treasury of the TNI institution. The type and approach used in this research is } \\
\text { normative legal research. The approach used is the statute approach, the case } \\
\text { approach, and the conceptual approach. Sources of research using primary legal } \\
\text { materials and secondary legal materials. Collection of legal materials, namely, } \\
\text { looking for legal materials that are relevant to the issue at hand. Analysis of legal } \\
\text { materials using deductive and inductive methods. } \\
\text { Keywords: Indonesian National Army, Government Institutions, Country. } \\
\text { Abstrak } \\
\text { Militer di Indonesia telah banyak terlibat dalam kehidupan sosial politik dalam } \\
\text { menentukan kebijakan negara. Keterlibatan ini ke dalam ranah sosial-politik yang } \\
\text { telah dimulai sejak berdirinya negara ini 1945-1998 dan dikenal dengan sebutan } \\
\text { Dwifungsi ABRI. Namun adanya konsep Dwifungsi ABRI dinilai sebagai penyebab } \\
\text { gagalnya sistem pemerintahan yang ada di Indonesia. Dengan banyaknya tuntutan } \\
\text { reformasi dan jatuhnya rezim orde baru, maka pada tahun } 2000 \text { tepatnya bulan Mei } \\
\text { konsep Dwifungsi secara resmi dihapus dari khazanah institusi TNI. Jenis dan } \\
\text { pendekatan yang digunakan pada penelitian ini adalah penelitian hukum normatif. } \\
\text { Pendekatan yang digunakan adalah pendekatan Undang-Undang (statute approach), } \\
\text { pendekatan kasus (case approach) dan pendekatan konseptual (conceptual approach). } \\
\text { Sumber penelitiannya menggunakan bahan hukum primer dan bahan hukum } \\
\text { sekunder. Pengumpulan bahan hukum yaitu, mencari bahan-bahan hukum yang } \\
\text { relevan terhadap isu yang dihadapi. Analisis bahan hukum menggunakan metode } \\
\text { deduktif dan induktif. } \\
\text { Kata Kunci: Tentara Nasional Indonesia, Lembaga Pemerintahan, Negara. }\end{array}$ \\
\hline
\end{tabular}

\section{Pendahuluan}

Setiap bangsa dalam rangka mempertahankan eksistensinya untuk mewujudkan citacita dan tujuan nasionalnya harus memiliki suatu ketahanan nasional. Berdasarkan dari hal tersebut maka dibentuklah badan atau tenaga militer dengan nama Badan Keamanan Rakyat (BKR) pada tanggal 22 Agustus 1945 dan baru pada 3 Juni 1947 diganti namanya menjadi TNI (Tentara Nasional Indonesia). Setelah sebelumnya mengalami dua kali pergantian nama dari 
BKR pada tanggal Oktober 1945 menjadi TKR (Tentara Keselamatan Rakyat) pada 1 Januari $1946 .{ }^{1}$

Sebagaimana kita ketahui, militer di Indonesia telah banyak terlibat dalam kehidupan sosial politik dalam menentukan kebijakan negara. Bila kita cermati keterlibatan militer/TNI ini, sepertinya tidak bisa terlepas dari faktor sejarah yang membentuknya. Keterlibatan TNI ke dalam ranah sosial-politik yang dimulai dari sejak berdirinya negara ini 1945 hingga tahun 1998, yang kemudian secara resmi pada tahun 2000 keterlibatan sosial politik ini dihapus dari khazanah institusi TNI. ${ }^{2}$

Latar belakang dan alasan tersebut di atas digaris bawahi oleh pendapat dari Moh. Mahfud MD yang mengatakan bahwa Peran serta TNI dalam dunia politik karena berdasarkan pengalaman sejarah, pemerintahan sipil telah gagal menjalankan pemerintahan yang stabil. Ini bisa dilihat dari perjalanan demokrasi liberal yang didukung oleh banyak parpol yang cenderung menghalangi kinerja pemerintah untuk menjadi baik, sehingga muncul berbagai pemberontakan. TNI tidak ingin diposisikan sebagai pemadam kebakaran sehingga harus mengambil peran secara proaktif dalam mengambil keputusan politik agar negara tidak terjerumus ke dalam kehancuran karena ancaman-ancaman yang tidak diantisipasi dengan baik. ${ }^{3}$

Namun kriteria tentang segala peran politik militer yang begitu dominan di Indonesia kelihatannya menyusut tajam bersamaan dengan pasca runtuhnya Orde Baru. Hal itu dapat dilihat dari tuntutan akan reformasi yang begitu kuat, dengan mempromosikan proses demokratisasi, telah merubah secara fundamental hubungan sipil militer di Indonesia. Walaupun demikian, TNI masih tetap memiliki peran strategis dalam agenda reformasi di Indonesia dalam membangun sistem pemerintahan yang demokratis. Peran strategis ini merupakan warisan sejarah politik Orde Baru yang menempatkan militer sebagai pemain sentral dalam perpolitikan melalui konsep Dwifungsi ABRI. ${ }^{4}$

Konsep Dwifungsi ABRI atau yang disebut dengan "konsep jalan tengah" antara bentuk pemerintahan sipil yang berpaling ke paham barat (pemerintahan liberal) dan pemerintahan militer seperti di Amerika Latin di masa itu. Konsep ini yang melatarbelakangi pemahaman bahwa militer (TNI/ABRI) dalam peran sejarah dan tanggung jawab TNI tidak hannya memperjuangkan dan pemeliharaan kemerdekaan, namun juga sebagai instrumen penentu dalam pembangunan sehingga TNI tidak hanya dianggap sebagai alat yang mati. Namun dalam keterlibatannya harus dijaga jangan sampai membentuk pemerintahan junta militer. Konsep jalan tengah/keseimbangan inilah yang kemudian dikenal dengan konsep Dwifungsi ABRI.

Kemudian dengan munculnya tuntutan reformasi yang ditandai dengan tumbangnya rezim Orde Baru, konsep Dwifungsi justru dianggap sebagai penyebab gagalnya suatu pemerintahan di Indonesia, sehingga TNI dianggap sebagai salah satu penyebab yang dominan, maka agenda reformasi tidak dapat dibendung untuk mempersoalkan peran militer dalam politik melalui konsep Dwifungsi-nya. TNI sendiri menyadari bahwa tuntutan reformasi harus direspons secara positif karena mereka tidak dapat mengelak dari kenyataan tentang akibat-akibat buruk dari penerapan Dwifungsi itu. Berdasarkan kesadaran itulah

${ }^{1}$ Andrizal, “Analisis Yuridis Tentang Kedudukan Tentara Nasional Indonesia (TNI) Setelah Berlakunya UndangUndang Nomor 34 Tahun 2004," (Jurnal Ilmu Hukum 2014), 111

2 Bilveer Singh, Dwifungsi ABRI (Jakarta: PT Gramedia Pustaka Utama, 1995), 44.

${ }^{3}$ Moh Mahfud MD, Perdebatan Hukum Tata Negara (Jakarta: LP3ES Indonesia, 2007), 84.

${ }^{4}$ Connie Rahakundini Bakrie, Pertahanan Negar \& Postur TNI Ideal (Jakarta: Yayasan Obor Indonesia, 2007$), 3$. 
pada bulan Mei tahun 2000 konsep Dwifungsi secara resmi dihapus dari khazanah institusi TNI.

Sebagai akibat besarnya desakan terhadap militer untuk kembali padaa peran pertahanan negara, menyebabkan TNI mereposisi dan meredefinisi fungsi dan perannya sebagai alat pertahanan negara. Panglima TNI Laksamana Widodo AS, dalam Rapat Pimpinan (Rapin) TNI tanggal 19-20 Mei 2000 di Cilangkap, menyatakan secara tegas bahwa TNI telah meninggalkan fungsi sosial-politik serta melepaskan fungsi keamanan menjadi wewenang dan tanggung-jawab Polri. ${ }^{5}$ Dengan demikian TNI kembali kepada jati dirinya sebagai tentara profesional yang berperan sebagai alat pertahanan NKRI (Negara Kesatuan Republik Indonesia). Langsung maupun tidak, bisa dikatakan bahwa secara formal peran Dwifungsi ABRI sudah berakhir. Keputusan ini adalah jawaban final TNI terhadap tekanan dari masyarakat, terutama sejak jatuhnya Orde Baru (lengsernya Presiden Soeharto), agar TNI meninggalkan lapangan politik dan penanganan keamanan dalam negeri, dan hanya memusatkan perhatian mereka sebagai alat pertahanan negara.

Dengan melihat kenyataan yang ada saat itulah, TNI telah merubah dirinya menajadi alat Pertahanan Negara yang profesional dengan tidak melibatkan diri dalam kehidupan berpolitik baik secara langsung dan tidak langsung sebagai konsekuensi atas tuntutan reformasi yang disambut positif oleh TNI dengan mendorong ke arah percepatan pembangunan masyarakat sipil dari aspek hubungan sipil-militer di Indonesia yang diharapkan untuk saling dijaga bersama agar tidak terjadi terulangnya kekeliruan yang sama. ${ }^{6}$ Maka dari itu peneliti tertarik untuk melakukan penelitian terhadap kedudukan dan peran TNI setelah dikeluarkannya UU No. 34 Tahun 2004 Tentang Kedudukan Dan Peran Tentara Nasional Indonesia Dalam Lembaga Kepemerintahan Negara.

\section{Rumusan Masalah}

Adapun permasalahan yang diangkat menjadi pokok masalah sebagai berikut:

1. Bagaimana kedudukan dan peran Tentara Nasional Indonesia dalam Lembaga Kepemerintahan Negara menurut UU No. 34 Tahun 2004?

2. Bagaimana kedudukan lembaga kepemerintahan negara dalam Undang- Undang Dasar 1945?

3. Bagaimana dampak-dampak terhadap lembaga kepemerintahan Negara atas penerapan Pasal 47 UU No. 34 Tahun 2004?

\section{Metode Penelitian}

Jenis penelitian dalam penelitian ini adalah penelitian hukum normatif disebut juga penelitian hukum doktrinal. Pada penelitian hukum jenis ini acapkali hukum dikonsepsikan sebagai apa yang tertulis dalam peraturan perundang-undangan (law in book) atau hukum yang dikonsepkan sebagai kaidah atau norma yang merupakan patokan berperilaku manusia yang dianggap pantas. Oleh karena itu, sebagai sumber datanya hanyalah data sekunder, yang terdiri dari bahan hukum primer, bahan hukum sekunder, dan bahan hukum tersier.

\footnotetext{
5 Salim Said, Tumbuh dan Tumbangnya Dwifungsi: Perkembangan Pemikiran Politik Militer Indonesia (Jakarta: Aksara Kurnia, 2002), 1.

${ }^{6}$ Moh Mahfud MD, Perdebatan Hukum Tata Negara, 53.
} 
Pendekatan-pendekatan yang digunakan di dalam penelitian hukum ini adalah pendekatan Undang-Undang (statute approach), dan pendekatan konseptual (conceptual approach).

Sumber data yang digunakan dalam penelitian ini yaitu terdiri atas tiga jenis yaitu sumber data primer, sekunder dan tersier. Sumber data primer berasal dari perundangundangan seperti UU No. 34 Tahun 2004 Tentang TNI. Adapun sumber data sekunder bersumber dari buku-buku hukum yang ada relevansinya dengan penelitian ini termasuk juga skripsi, tesis, disertasi dan jurnal-jurnal hukum. Sedangkan sumber data tersier bersumber dari bahan non hukum yang dirasa perlu untuk mengidentifikasi dan menganalisa fakta secara akurat dan menemukan isu hukum atas fakta tersebut. Adapun teknik pengumpulan data pada penelitian ini yaitu dengan cara deduktif yakni berupa pola pikir yang berangkat dari pemahaman yang bersifat umum kemudian ditarik pada kesimpulan yang bersifat khusus.

\section{Hasil dan Pembahasan}

Kedudukan dan Peran Tentara Nasional Indonesia dalam Lembaga Kepemerintahan Negara Perspektif UU No. 34 Tahun 2004 Tentang Tentara Nasional Indonesia

Dengan berlakunya UU No. 34 Tahun 2004 Tentang TNI, kedudukan TNI sebagai militer di Indonesia juga mengalami perubahan. Hal ini sesuai dengan Pasal 3 UU No. 34 Tahun 2004 yang berisi: ${ }^{7}$

1) Dalam pengerahan dan penggunaan kekuatan militer, TNI berkedudukan di bawah presiden.

2) Dalam kebijakan dan strategi pertahanan dan dukungan administrasi TNI di bawah koordinasi Departemen Keamanan.

Berdasarkan ketentuan Pasal 3 Ayat (1) di atas menunjukkan kedudukan TNI dalam menjalankan fungsi dan peranannya adalah sebagai alat pertahanan negara. Tentunya TNI ketika melaksanakan pengarahan dan penggunaan kekuatan militer mestinya atas dasar kebijakan presiden kedudukan di bawah presiden, serta di bawah kekuasaan presiden.

Dengan demikian maka untuk memainkan kedudukannya sebagai militer Indonesia hanya bisa mengikuti keputusan yang ditetapkan oleh pemerintah. Dengan kata lain, TNI hanya bisa tunduk untuk melaksanakan kedudukannya yang telah diputuskan oleh pemerintah. Artinya, untuk menjalankan kedudukannya itu TNI tidak bisa hanya berdasarkan kebijakan panglima tertinggi TNI semata. Tapi mesti atas dasar kebijakan politik nasional yang ditetapkan bersama-sama antar presiden dan DPR. ${ }^{8}$

Melihat dari sistem trias politika kedudukan Tentara Nasional Indonesia (TNI) berada di wilayah Eksekutif, dengan diperkuatnya dalam pasal 3 UU No. 34 Tahun 2004 tentang Tentara Negara Indonesia bahwa kedudukan TNI berada di bawah presiden melalui Departemen Keamanan.

Dalam perubahan Undang-Undang 1945 tentang Tentara Nasional Indonesia Pasal 30 ayat 3 disebutkan bahwa Tentara Nasional Indonesia terdiri atas Angkatan Darat, Angkatan Laut, dan Angkatan Udara sebagai alat negara bertugas mempertahankan, melindungi, memelihara keutuhan dan kedaulatan negara. Selanjutnya disebutkan mengenai peran TNI

7 Pasal 3 Undang-Undang Nomor 34 Tahun 2004 Tentang Tentara Nasional Indonesia. 
dalam Pasal 5 UU No. 34 tahun 2004 yaitu, TNI berperan dalam sebagai alat negara di bidang pertahanan yang dalam menjalankan tugasnya berdasarkan kebijakan dan keputusan politik negara. Yang dimaksud dengan kebijakan dan keputusan politik negara adalah kebijakan politik pemerintah bersama sama Dewan Perwakilan Rakyat yang dirumuskan melalui mekanisme hubungan kerja antara pemerintah dan Dewan Perwakilan Rakyat, seperti rapat konsultasi dan rapat kerja sesuai dengan perundang-undangan. ${ }^{9}$

\section{Kedudukan Lembaga Kepemerintahan Negara dalam Undang-Undang Dasar 1945}

Sistem ketatanegaraan di Indonesia tertuang dalam Penjelasan Undang Dasar Negara Republik Indonesia Tahun 1945 tentang (tujuh) kunci pokok sistem pemerintahan, yaitu:

1. Indonesia adalah negara yang berdasar atas hukum (rechtstaat)

2. Sistem konstitusional

3. Kekuasaan tertinggi di tangan Majelis Perwakilan Rakyat

4. Presiden adalah penyelenggara pemerintah negara yang tertinggi di bawah Majelis Perwakilan Rakyat

5. Presiden tidak bertanggungjawab kepada Dewan Perwakilan Rakyat

6. Menteri Negara adalah pembantu presiden dan tidak bertanggungjawab terhadap Dewan Perwakilan Rakyat

7. Kekuasaan Kepala Negara tidak tak terbatas

Berdasarkan 7 (tujuh) kunci pokok tersebut, sistem pemerintahan Indonesia menurut Undang Dasar Negara Republik Indonesia Tahun 1945 menganut sistem Presidensial. ${ }^{10}$

Merujuk pada ketentuan pasca diamandemennya UUD NRI Tahun 1945, maka seyogianya dipahami bahwa setiap lembaga negara mempunyai kedudukan yang sederajat, yang mana berbeda dengan kedudukan lembaga negara pada masa sebelum amandemen yang mengenal konsep lembaga tertinggi dan lembaga tinggi negara. Hal tersebut dipahami karena konsep lembaga tertinggi negara dipegang oleh MPR pada masa itu yang kemudian diikuti di bawahnya oleh lembaga tinggi negara lainnya yang menjalankan fungsinya masingmasing dan GBHN (Garis Besar Haluan Negara) yang disahkan oleh MPR. Namun, konsep tersebut dihilangkan setelah amandemen UUD NRI Tahun 1945, dengan menempatkan MPR sebagai lembaga yang sederajat dengan lembaga lainnya. ${ }^{11}$

Ada dua unsur pokok yang saling berkaitan ketika berbicara mengenai organisasi negara yakni organ dan functie. Organ adalah bentuk atau wadahnya, sedangkan functie adalah isinya. Macam-macam organ negara/lembaga negara dapat dibedakan dari beberapa segi yakni; Pembedaan dari segi Hierarkinya/dari Segi Landasan Hukum Pembentukannya dan Pembedaan dari Segi fungsinya.

\section{Dampak-dampak terhadap Lembaga Kepemerintahan Negara atas Penerapan Pasal} 47 UU No. 34 Tahun 2004

Dalam pasal 47 UU No. 34 Tahun 2014 yang berbunyi : ${ }^{12}$

\footnotetext{
9 Penjelasan Pasal 6 Undang-Undang Nomor 34 Tahun 2004 Tentang TNI

${ }^{10}$ Tri Mulyani, “Kajian Normatif Mengenai Hubungan Antar Lembaga Negara Dalam Sistem Ketatanegaraan Republik Indonesia Berdasarkan Undang-Undang Dasar Tahun 1945: Sebelum Dan Sesudah Amandemen", Humani 6, no.1 (Januari, 2016): 84.

${ }^{11}$ Zaki Ulya, Hukum Kelembagaan Negara (Aceh: Universitas Samudra, 2019), 31

12 Pasal 47 Undang-Undang Nomor 34 Tahun 2004 Tentang TNI
} 
1. Prajurit hanya dapat menduduki jabatan sipil setelah mengundurkan diri atau pensiun dari dinas aktif keprajuritan.

2. Prajurit aktif dapat menduduki jabatan pada kantor yang membidangi koordinator bidang Politik dan Keamanan Negara, Pertahanan Negara, Sekretaris Militer Presiden, Intelijen Negara, Sandi Negara, Lembaga Ketahanan Nasional, Dewan Pertahanan Nasional, Search and Rescue (SAR) Nasional, Narkotik nasional, dan Mahkamah Agung.

3. Prajurit menduduki jabatan sebagaimana dimaksud pada ayat (2) didasarkan atas permintaan pimpinan departemen dan lembaga pemerintahan non departemen serta tunduk pada ketentuan administrasi yang berlaku dalam lingkungan departemen dan lembaga pemerintah non departemen dimaksud.

4. Pengangkatan dan pemberhentian jabatan bagi prajurit sebagaimana dimaksud pada ayat (2) dilakukan sesuai dengan kebutuhan organisasi departemen dan lembaga pemerintah non departemen yang bersangkutan.

5. Pembinaan karier prajurit yang menduduki jabatan sebagaimana dimaksud pada ayat (2) dilaksanakan oleh Panglima bekerja sama dengan pimpinan departemen dan lembaga pemerintah non departemen yang bersangkutan.

6. Ketentuan sebagaimana dimaksud pada ayat (2), ayat (3), dan ayat (4) diatur dengan Peraturan Pemerintahan.

Menumpuknya perwira tinggi dan menengah yang tidak memegang jabatan struktural harus diakui memang menjadi problem bagi TNI. Saat ini saja, tidak kurang dari 650 perwira di lingkungan TNI tidak memiliki jabatan struktural. Jumlah itu terdiri atas 150 perwira tinggi dan 500 perwira menengah berpangkat kolonel. Melonjaknya jumlah perwira TNI baik menengah maupun tinggi yang tidak memiliki jabatan ini dilatari oleh setidaknya tiga faktor:

1. Berakhirnya Dwifungsi ABRI sejak era Reformasi menyebabkan banyak perwira tinggi kehilangan jabatan. Seperti kita tahu, Dwifungsi ABRI memungkinkan perwira TNI menduduki jabatan-jabatan strategis di instansi sipil. Sejak kebijakan tersebut dicabut, TNI tidak lagi memiliki keleluasaan untuk menduduki jabatan di lingkungan sipil.

2. Berlakunya aturan baru terkait batas usia pensiun jenderal yang tadinya 55 tahun menjadi 58 tahun sebagaimana diatur dalam UU No. 34 Tahun 2004. Pemerintah agaknya kurang mengantisipasi dampak pemberlakuan aturan baru tersebut sehingga manajemen personel dan kaderisasi di tubuh TNI kurang berjalan maksimal. Konsekuensinya, terjadi penumpukan perwira menengah dan tinggi, sementara jabatan struktural yang tersedia terbatas.

3. Rekrutmen Sekolah Staf dan Komando Militer di tiga matra (Angkatan Darat, Air, dan Udara) yang tidak dirampingkan. Sebagai gambaran, setiap tahun ada sekitar 300 lulusan Sekolah Staf dan Komando Angkatan Darat, sedangkan jabatan struktural yang tersedia tidak lebih dari separuh dari jumlah lulusan tersebut.

Menumpuknya perwira tinggi dan menengah tentu berdampak negatif, tidak hanya bagi internal TNI, namun juga bagi negara dalam konteks luas. Bagi internal TNI, keberadaan perwira tinggi dan menengah non-job tentu akan menimbulkan kecemburuan antar anggota yang potensial berujung pada munculnya persaingan tidak sehat. Sudah menjadi semacam rahasia umum bahwa perebutan jabatan struktural di tubuh TNI acapkali diwarnai oleh transaksi suap, bahkan tidak jarang melibatkan intrik politik. Kondisi yang demikian itu tentu 
berpengaruh secara langsung terhadap negara karena TNI merupakan institusi pertahanan dan keamanan negara. ${ }^{13}$

\section{Kesimpulan}

TNI berkedudukan di bawah Presiden, sedangkan dalam kebijakan dan strategi pertahanan serta dukungan administrasi, TNI di bawah koordinasi Departemen Pertahanan, dengan demikian TNI hanya berperan sebagai alat negara di bidang pertahanan yang dalam menjalankan tugasnya berdasarkan kebijakan dan keputusan politik negara.

Pasca diamandemennya UUD NRI Tahun 1945, maka setiap lembaga negara mempunyai kedudukan yang sederajat, yang mana berbeda dengan kedudukan lembaga negara pada masa sebelum amandemen yang mengenal konsep lembaga tertinggi dan lembaga tinggi negara.

Dampak dari revisi UU TNI ialah kembalinya TNI menjadi institusi dengan dua peran (Dwifungsi ABRI), yakni di bidang militer dan sipil. Hal ini akan memicu kecemburuan internal kepemerintahan sipil dan rusaknya pola karier TNI di kementerian/lembaga.

\section{Daftar Pustaka}

\section{Buku}

Bakrie, Connie Rahakundini. 2007. Pertahanan Negara \& Postur TNI Ideal. Jakarta: Yayasan Obor Indonesia, 2007.

Mahfud MD, Moh. 2007. Perdebatan Hukum Tata Negara. Jakarta: LP3ES Indonesia.

Said, Salim. 2002. Tumbuh dan Tumbangnya Dwifungsi: Perkembangan Pemikiran Politik Militer Indonesia. Jakarta: Aksara Kurnia.

Singh, Bilveer. 1995. Dwifungsi ABRI. Jakarta: PT Gramedia Pustaka Utama.

Ulya, Zaki. 2019. Hukum Kelembagaan Negara. Aceh: Universitas Samudra.

\section{Jurnal}

Andrizal. "Analisis Yuridis Tentang Kedudukan Tentara Nasional Indonesia (TNI) Setelah Berlakunya Undang-Undang Nomor 34 Tahun 2004." Jurnal Ilmu Hukum (2014): 111113

Tri Mulyani. “Kajian Normatif Mengenai Hubungan Antar Lembaga Negara Dalam Sistem Ketatanegaraan Republik Indonesia Berdasarkan Undang-Undang Dasar Tahun 1945: Sebelum Dan Sesudah Amandemen" Humani 6, no. 1 (Januari, 2016): 84.

\section{Laman}

https://m.detik.com/news/kolom/d-4447685/wacana-revisi-uu-tni-dan-ancaman

\section{Perundang-Undangan}

Undang-Undang Nomor 34 Tahun 2004 Tentang Tentara Nasional Indonesia.

${ }^{13}$ https://m.detik.com/news/kolom/d-4447685/wacana-revisi-uu-tni-dan-ancaman militerisme. Diakses 13/7/2019, Jam 15:30 WIB. 